\title{
Rural Development Dimension of Agriculture Policy: A Case of Nepal
}

\author{
Ganesh Prasad Chalise ${ }^{1}$, Kiran Ghimire ${ }^{2}$ Sujan Dhungel ${ }^{3}$ and Arun GC ${ }^{4}$,
}

\begin{abstract}
The majority of the population in developing countries resides in the rural area. Development itself cannot address the challenges of the rural area since its economic, political and environmental landscape is different from an urban area. The paper attempts to assess the rural dimension aspect of Nepali Agriculture Policy since rural development and agricultural development is closely resembled due to an agrarianbased economy of the country and a large rural population. Therefore, a critical review of National Agriculture Policy, 2004 (NAP-2004) was carried out under "Commercialization of Agriculture", "Food Security", "Rural Infrastructure", "Gender", "Climate Change” and "Social Inclusion" thematic area. The results showed that NAP-2004 satisfactorily address rural development albeit ample space for improvement. The findings of the paper could be beneficial to policymakers and development workers in the field of rural development and agriculture along with academicians having interest in it.
\end{abstract}

Keywords: Rural Development, Nepal, Agriculture, Policy

\section{Introduction}

The concept of development is evolving and it started along with the civilization (Soares Jr. and Quintella, 2008). Along with development timeline, scholars realized that development of urban and rural is fundamentally different. Rural development is a multidimensional facets (Mahi uddin, Chowdhury, \& Ahmad, 2015) and is beyond economics, which covers social, political and environmental dimensions along with economics (Soares Jr. and Quintella, 2008). Rural development is generally characterized as a strategy, which enables the specific group of people who reside in the rural area (Acharya, 2008). It is also defined as the process of change in nonurban areas. Rural development policy is the sets of intervention that may find solutions to the challenges facing by the rural communities (Lucian, 2018). Moreover, it is also synonymously used with poverty dimension and poverty is also a multi-dimensional concept (Mahi uddin, Chowdhury, \& Ahmad, 2015).

\footnotetext{
${ }^{1}$ Prime Minister Agriculture Modernization Project, Government of Nepal

2 Plant Protection and Pesticide Management Center, Government of Nepal

${ }^{3}$ Ministry of Agriculture and Livestock Development, Government of Nepal

${ }^{4}$ Ministry of Agriculture and Livestock Development, Government of Nepal: gcarun88@gmail.com
} 
The essence of the rural development is to bring modernity from the city to the rural landscape and more importantly to the agriculture (Guinjoan, Badia, \& Tulla, 2016). Moreover, the Washington consensus has brought agriculture and rural development together with stronger bond (Maxwell, Urey, \& Ashley, 2001).

Nepal is an agrarian nation (GC \& Ghimire, 2018b; Ghimire \& GC, 2018a), which produces one-third of Gross Domestic Product (GDP) and retains two-thirds of labour forces (MoF, 2016). The majority of people in Nepal reside in the rural area. Around 80 per cent of the total population and 90 per cent of the total poor are living in a rural area (NPC, 2018). Moreover, rural development in Nepal cannot be achieved without the commercialization of agriculture and the mobilization of local resources in an inclusive way (Acharya, 2008). Therefore, assessing agricultural policy is crucial to meet the challenges of the rural landscape.

National Agriculture Policy, 2004 (NAP-2004) is a guiding policy of Nepal in the agriculture sector (GC $\&$ Ghimire, 2018a). The NAP-2004 deals with the agriculture sector of Nepal. However, we have tried to assess NAP-2004 from the rural dimension perspective. 


\section{Methodology}

The qualitative analysis was done for this paper. The critical review of NAP-2004 was done from the rural development perspective. Several peer-reviewed papers and other publications were accessed and reviewed. The database for journal articles "Directory of Open Access Journals" (DOAJ), Researchgate, and Google Scholar was used to search literature. The papers were searched using the keywords "Rural Development", "Rural Economy" and "Sustainable Rural Development". The NAP-2004 has accessed the web portal of the Nepal Law Commission (www.lawcommission.gov.np ).

In the Nepali context, the goal of rural development means to achieve commercialization of agriculture, rural employment, ensuring food security, infrastructure development and modernization of overall development (Acharya, 2008). Similarly, gender issues, climate change, social inclusions are other key issues of rural development. Therefore, we assessed NAP-2004 from the aforementioned dimensions of the rural development.

\section{Results and Discussion}

The NAP-2004 was assessed from the rural development dimension under "Commercialization of Agriculture", "Food Security", "Rural Infrastructure", "Gender", "Climate Change” and "Social Inclusion”. Each thematic area is discussed separately hereunder.

\section{a. Commercialization of Agriculture}

Nepali agriculture is still characterized as subsistence agriculture. Therefore, commercialization is the major issue for agriculture development. Without commercialization of agriculture, rural development of Nepal is not likely to happen. The NAP-2004 has a dedicated section for commercialization and competitiveness of agriculture. The section has 23 different policy options. The large production pockets based on comparative advantage was considered as the base for commercialization and competitiveness of agriculture. Moreover, integration of technical service, agriculture road, rural electrification, irrigation, agriculture loan and market development were taken as the foundation for commercialization and competitiveness. The policy option for the promotion of local production, a double track system for the government farms, the introduction of agriculture and livestock insurance, promotion of cooperative-based agricultural industries, highvalue agriculture and encouragement of contract farming are some provision of NAP-2004 for the purpose of commercialization. Likewise, provision of improved agriculture technology along with technical services and training are prioritized in the NAP-2004. These policy options are found enabling clutches for rural development in Nepal. However, a clear policy option for an increment 
of rural farm income cannot be trace-out in the NAP-2004 albeit sufficient indirect linkages are found in the NAP-2004.

\section{b. Food Security}

Food Security is an evolving concept. At an early stage of development, sufficient production of agriculturally produced at the national level was supposed food security. However, currently, it was defined by four dimension- availability, access, utilization and stability. The general objective of NAP-2004 explicitly spells-out the food security along with poverty reduction. Nevertheless, food security cannot secure its place in the specific objective of the NAP-2004.

In the NAP-2004, the first section of sets of policy deals with enhancement of production and productivity. Therefore, broadly, we can consider these policy options to fulfil the availability dimension of food security. Likewise, there is a separate section which is dedicated to the targeted group. The targeted group was classified as the farmers having less than half hector of land, lower level of irrigation facilities, Dalit (lower cast), oppressed and marginalized farmers and farm labours. Although the policy options are related to agriculture production rather than food security, these options certainly contribute to the access dimension of food security. Likewise, a the provision of food safety net also support the food security for the targeted group. However, utilization dimension and stability dimension of the food security cannot be clearly traced in the NAP-2004.

\section{c. Rural Infrastructure}

Irrigation, agriculture roads, rural electrification, agriculture commodities collection centers, processing centers, etc are the rural infrastructure related to agriculture. Likewise, provision of the market information system, agriculture market, gene bank, training facilities is another policy option will is closely related to rural infrastructures. The important thing is we cannot confirm that these sets of rural infrastructure related to agriculture are sufficient for rural development. However, many of these infrastructures are not explicitly agricultural. For instance, the agricultural road does not necessarily mean only for agriculture. Therefore, agricultural rural infrastructures are the strong subset of rural infrastructure.

\section{d. Gender}

Mainly gender issues in agriculture in especial and rural development in general are - ownership over resources, decision-making role and development and the introduction of women-friendly tools and implements. However, NAP-2004 has not explicitly addressed these issues. Nevertheless, the NAP-2004 has clearly laid policy to increase women participant in the agriculture program. The NAP-2004 stated that the women participating in the agriculture program will be brought to 50 per cent and the women target training will be carried out as near to their locality as possible. More 
importantly, access of women to the information on such program is a big issue. Therefore, the NAP-2004 has lauded that information flow to them will be ensured.

\section{e. Climate Change}

Climate change is a burning issue and Nepal is one of the most vulnerable countries (GC, 2017). Moreover, the impact of climate change is anticipated much higher to resource-poor farmers whose adaptation capacity is supposed to be much lower. More importantly, the impact of climate change in agriculture is more prominent in the case of agriculture bases countries like Nepal. However, NAP-2004 has not provided any concrete policy options directly related to climate change. Nevertheless, some technology promoted by NAP-2004 can greatly support climate change adaptation. For instance, promotion of drip irrigation, water harvesting, biodiversity promotion and management and the provision of survey-surveillance are few among them.

\section{f. Social Inclusion}

A special section was dedicated to the target group. As already mentioned before the target group was defined as the farmers having less than half hector of land, lower level of irrigation facilities, Dalit (lower cast), oppressed and marginalized farmers and farm labours. Policy option to increase access to land for target group was formulated in a clear way. The concept of a land bank is also brought to increase access to land for targeted groups. A provision of free seeds and technical service was sought to oppressed, Dalit and marginalized farmers if they come up as a group. Likewise, special facilities were proposed for small irrigation to those target groups. More importantly, the provision of Food and Nutrition Security Safety Net to those target groups could be considered as a great milestone for social inclusion and food security as well.

\section{Conclusion}

Nepal being an agriculture-based country, rural development and agriculture development has muchoverlapped scopes. There are only a few areas of rural development, which merely does not overlap the scope of agriculture. Therefore, sound agriculture policy is very crucial for overall rural development of the country. The NAP-2004 is a guiding policy for agriculture section, although other sectoral policies are already in function under the umbrella of NAP-2004. The analysis of NAP-2004 found that it satisfactorily addresses several issues and prospects of rural development. However, ample space of development was identified under climate change and social inclusion along with gender in the NAP-2004. Nevertheless, NAP-2004 can be categorized as a good agriculture policy, which could support rural development in Nepal. Moreover, the implementation matter much than the policy itself. 


\section{References}

Acharya, B. R. (2008). Dimension of Rural Development in Nepal. Dhaulagiri Journal of Sociology and Anthropology, 181-192.

GC, A. (2017). Perception to Adaptation of Climate Change in Nepal: An Empirical Analysis using Multivariate Probit Model (Masters' Degree Thesis). Daegu: Kyungpook National University. Retrieved from https://www.researchgate.net/publication/323004830_Perception_to_Adaptation_of_Climate_ Change_in_Nepal_An_Empirical_Analysis_using_Multivariate_Probit_Model

GC, A., \& Ghimire, K. (2018a). A SWOT Analysis of Nepalese Agriculture Policy. Int. J. Agric. Environ Food Sci, 119-123.

GC, A., \& Ghimire, K. (2018b). Determinats of Pesticide Application in Nepalese Vegetable Farming: An Empirical Analysis Using Multivariate Probit Model. The Journal of Agriculture and Environment, 42-50.

Ghimire, K., \& GC, A. (2018). Trend of Pesticide Use in Nepal. Journal of the Plant Protection Society, 3242.

Guinjoan, E., Badia, A., \& Tulla, A. F. (2016). The New Paradigm of Rural Development, Theoretical Consideration and Reconceptualization Using the Rural Web. Boletin de la Asociacion de Geografos Esponoles, 495-500.

Lucian, P. (2018). Durable Rural Development Through the 2014-2020 National Rural Development Program. Studies in Business and Economics, 147-152.

Mahi uddin, M., Chowdhury, M. M., \& Ahmad, A. (2015). The Impact of Rural Development Program on Poverty Alleviation: A Case of Bangladesh. Global Journal of Managment and Business Research: A Administration and Managment, 17-24.

Maxwell, S., Urey, I., \& Ashley, C. (2001). Emerging Issues in Rural Development. London: Overseas Development Insitute.

MoF. (2016). Economic Survey Fiscal Year 2016/17. Kathmandu: Ministry of Finance (MoF), Government of Nepal.

NPC. (2018). Nepal Multidimensional Poverty Index. Kathmandu: National Planning Commission (NPC) of Nepal.

Soares Jr., J., \& Quintella, R. H. (2008). Development: an Analysis of Concepts, Measurement and Indicators. Brazilian Administration Review, 5(2), 10-124. Retrieved from http://www.scielo.br/pdf/bar/v5n2/v5n2a03.pdf 